\title{
IMPLEMENTASI PROBLEM-BASED LEARNING UNTUK MENINGKATKAN HASIL BELAJAR KOGNITIF, PSIKOMOTOR, DAN AFEKTIF SISWA DI SMK
}

\author{
Muhammad Nurtanto \\ PTK PPs UNY Universitas Negeri Yogyakarta \\ mnurtanto@gmail.com \\ Herminarto Sofyan \\ PTK PPs UNY Universitas Negeri Yogyakarta \\ hermin@uny.ac.id
}

\begin{abstract}
Abstrak
Penelitian ini bertujuan untuk meningkatkan keaktifan pembelajaran dan hasil belajar siswa pada kompetensi dasar sistem pengapian konvensional dalam mengimplementasikan metode problembased learning. Penelitian ini menggunakan penelitian tindakan kelas yang dilaksanakan dalam dua siklus, masing-masing siklus terdiri dari empat tahapan: perencanaan, pelaksanaan, pengamatan, dan refleksi. Data dianalisa secara deskriptif. Hasil penelitian menunjukkan sebagai berikut: (1) keaktifan siswa meningkat sebesar 11,20\%; (2) keaktifan siswa kategori sangat tinggi sebanyak 36 siswa dan kategori tinggi sebanyak 3 siswa; (3) hasil belajar siswa aspek kognitif, psikomotor, dan afektif mengalami peningkatan masing-masing sebesar 5,32\%, 5,03\%, dan 2,05\%; dan (4) hasil belajar siswa aspek kognitif, psikomotor dan afektif yang mencapai kompetensi minimal masingmasing sebanyak 36 siswa (92,31\%), 36 siswa (92,31\%), dan 38 siswa (97,40\%) dari 39 jumlah siswa melalui penerapan problem-based learning.
\end{abstract}

Kata kunci: problem-based learning, aspek kognitif, aspek psikomotor, aspek afektif, hasil belajar

\section{THE IMPLEMENTATION OF PROBLEM-BASED LEARNING TO IMPROVE LEARNING OUTCOMES OF COGNITIVE, PSYCHOMOTOR, AND AFFECTIVE OF STUDENTS IN VOCATIONAL SCHOOL}

\begin{abstract}
This study aims to improve the learning activities and learning outcomes in learning conventional ignition system by implementing problem-based learning method. This study used a classroom action research which was conducted in two cycles, each cycle consisted of four phases: planning, implementation, observation, and reflection. The data were analyzed descriptively. The study results show that: (1) the learning activities increase as much as 11,20\%, (2) the category of learning activities is very high for 36 students and high for 3 students, (3) the cognitive, psychomotor, and affective aspects in learning outcomes of students increasing which each part is 5,32\%, 5,03\%, and 2,05\%, (4) the cognitive, psychomotor, and affective aspects in the learning outcomes reach minimum value criteria which each part is 36 students (92,31\%), 36 students (92,31\%), and 38 students $(97,40 \%)$ from 39 students with the implementation of problem-based learning.
\end{abstract}

Keywords: problem-based learning, cognitive aspects, psychomotor aspects, affective aspects, result of learning.

\section{PENDAHULUAN}

Tujuan utama pendidikan kejuruan adalah sarana pemenuhan diri atau akulturasi diri dimana siswa mampu mencari dan menemukan bakat, keterampilan, dan kemampuan untuk persiapan pekerjaan. Tujuan penyelenggaraan SMK tercantum dalam PP tahun 2005 nomor 19 tentang standar pendidikan nasional yaitu 
menyiapkan siswa untuk memasuki lapangan kerja mengembangkan sikap profesional. Sehingga, tujuan SMK menyiapkan siswa sebagai calon tenaga kerja dan mengembangkan eksistensi.

Menurut Wardiman Djojonegoro (1998, p.1), eksistensi dibagi menjadi 3 yaitu bagi siswa, dunia kerja, dan masyarakat. Eksistensi bagi siswa meliputi: peningkatan kualitas diri, peningkatan penghasilan, penyiapan pendidikan, penyiapan diri dan penyesuaian diri. Eksistensi bagi dunia kerja yaitu: memperoleh tenaga kerja berkualitas, meringankan biaya usaha, dan membantu memajukan dan mengembangkan usaha. Eksistensi bagi masyarakat berupa: peningkatan kesejahteraan, meningkatkan produktifitas dan penghasilan, serta mengurangi pengangguran.

Menurut Wardiman Djojonegoro (1998, p.2), tujuan dan manfaat pendidikan kejuruan dijelaskan dalam 9 karakteristik yaitu: (1) mempersiapkan memasuki lapangan kerja, (2) deman-dreven, (3) isi pendidikan ditekankan pada penguasaan pengetahuan, keterampilan, sikap, dan nilai, (4) penilaian pada hand-on, (5) hubungan dunia kerja, (6) responsif dan atisipatif terhadap kemajuan teknologi, (7) menekankan learning by doing dan handon eksperimence, (8) memerlukan fasilitas mutakhir untuk praktik, dan (9) memerlukan biaya investigasi dan oprasional.

Berdasarkan hasil survai yang dilakukan di SMK Ma'arif Salam pada bulan Agustus 2015, pengamatan yang dilakukan berupa administrasi pendukung dan pelaksanaan proses pembelajaran ditinjau dari aspek siswa, guru, dan fasilitas belajar. Temuan administrasi menunjukkan bahwa hasil belajar siswa kelas XI TKR tahun ajaran 2013/2014 masih rendah, yang ditunjukkan sebagai berikut.

Tabel 1. Hasil Belajar Pengapian Konvensional

\begin{tabular}{ccc}
\hline Kelas & Hasil Rata-Rata & $<$ KKM \\
\hline XIOA & 81,6 & 9 \\
XIOB & 79,6 & 9 \\
XIOC & 78,2 & 9 \\
XIOD & 79,1 & 9 \\
\hline
\end{tabular}

Rerata keseluruhan sebesar 79,6 dengan kompetensi minimal 70,0. Keseluruhan siswa nilai di atas kompetensi yang ditentukan, namun setelah dilakukan wawancara terhadap guru yang bersangkutan menunjukkan temuan bahwa nilai siswa kurang dari 75,0 sebenarnya belum mencapai kompetensi. Keseluruhan sebanyak 36 siswa (23\%). Hal ini menunjukkan pengetahuan dan keterampilan yang diperoleh masih rendah, dibuktikan dengan batas kompetensi minimal 70,0 dan masih sedikit siswa yang memperoleh nilai di atas 90,0.

Hasil wawancara dengan guru pengampu, ditemukan bahwa pelaksanaan praktik belum memiliki standar acuan penilaian, sehingga penilaian siswa belum mengukur kemampuan siswa secara terstruktur dan mendalam. Pelaksanaan pembelajaran menggunakan metode demonstrasi tanya jawab, dampaknya siswa kurang terkontrol secara keseluruhan. Dapat disimpulkan bahwa metode yang digunakan kurang berperan aktif dalam memperdayakan guru dan siswa. Pada hal, guru merupakan perencana pelaksanaan pembelajaran yang menentukan keberhasilan siswa. Fasilitias pembelajaran sangatlah mendukung pelaksanaan praktik, hanya saja kurang termanfaatkan dengan baik.

Paparan di atas menunjukkan hasil belajar siswa masih banyak yang belum mencapai kompetensi minimal dan pelaksanaan pembelajaran belum berpusat pada siswa aktif. Sehingga, pembelajaran sistem pengapian konvensional perlu adanya perubahan dengan menyeimbangkan aspek kognitif, aspek psikomotor, dan aspek afektif siswa. Aspek kognitif yang diterapkan meliputi: mengingat, memahami, mengaplikasikan, menganalisis, mengevaluasi, dan mencipta. Aspek psikomotor yang diterapkan meliputi persiapan kerja, proses kerja, hasil kerja, sikap kerja, dan waktu kerja. Aspek sikap terdiri dari sikap spiritual yang berhubungan dengan tuhan serta sikap sosial yang berhubungan terhadap sesama, adapun sikap tersebut meliputi: menghargai dan menghayati agama, jujur, toleransi, sopan/ santun, percaya diri, disiplin, tanggung jawab, kerja sama/gotong royong.

Berdasarkan keaktifan siswa dalam pelaksanaan pembelajaran dan meningkatkan 
hasil belajar aspek kognitif, psikomotor, dan afektif, maka diperlukan strategi yang tepat. Strategi yang digunakan yaitu pembelajaran berbasis problem-based learning. Menurut Rusman (2011, p.6), karakteristik dari $P B L$ adalah pembelajaran kontekstual dengan menekankan permasalahan sebagai starting point, permasalahan yang ada di dunia nyata tidak terstruktur, siswa mencari informasi dari berbagai sumber untuk mencari solusi permasalahan. Sehingga, dipercaya mampu meningkatkan keaktifan dan mengembangkan analitik siswa. Sejalan dengan Vardi \& Ciccarelli (2008, p.6), menyatakan: " $P B L$, effective strategies can be successfully employed to overcome commonly reported problems related to work load, and inadequate student preparation and participation in class activite".

\section{Hasil Belajar}

Hasil belajar merupakan kemampuankemampuan yang dimiliki peserta didik setelah mengikuti pembelajaran, Nana Sudjana (2013, p.22). UNESCO mengemukakan bahwa hasil belajar yang akan dicapai terdiri atas empat pilar, diantaranya: (1) learning to know (belajar mengetahui); (2) learning to do (belajar melakukan sesuatu); (3) learning to be (belajar menjadi sesuatu); dan (4) learning to live together (belajar hidup bersama). Hasil belajar ditandai dengan perubahan tingkah laku secara keseluruhan yang meliputi aspek kognitif, psikomotor, dan afektif. Proses perubahan dapat terjadi dari yang paling sederhana sampai yang paling kompleks.

Penilaian hasil belajar dilakukan untuk memperoleh jati diri seseorang (kompeten atau tidak kompeten) dalam penguasaan kemampuan. Sesuai ungkapan Brown, Kipral \& Rauner (2007, p.22), “That a person's skills, abilities, knowledge and experiences should match the specific requirements of a particular job was regarded as the main factor when making occupational decisions".

\section{Ranah Hasil Belajar}

Menurut Bloom (1956, p.24) membagi "learning domain" sebagai tujuan dirumuskan kedalam tiga klasifikasi atau aspek yaitu: (1) aspek cognitive; (2) aspek affective; dan (3) aspek psychomotor. Bloom's Taxonomy is a classification of learning objectives within education that educators set for students, ungkapan Omar, et. al. (2011, p.25).

Ranah kognitif Bloom dibagi menjadi 6 tingkatan yaitu pengetahuan (knowledge), pemahaman (comprehension), penerapan (application), analisis (analysis), sintesis (synthesis), dan evaluasi (evaluaton). Tahapan tingkat kognitif digambarkan sebagai berikut.

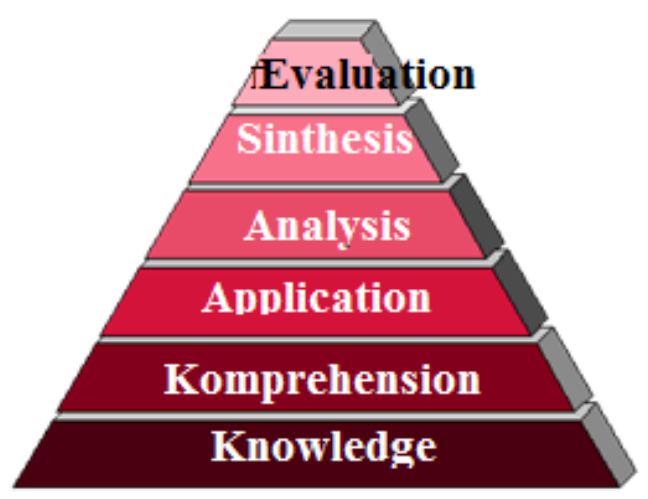

Gambar 1. Taksonomi Kognitif Bloom Sumber: Atherton (2013)

Revisi ranah kognitif Bloom bertujuan menyesuaikan pendidikan terkini, dimana kata benda berubah menjadi kata kerja. Huitt (2011, p.26), mengungkapkan "Keempat tingkatan sama seperti Bloom hirarki aslinya". Perbaikan ranah kognitif menurut Anderson \& Krothwahl (2011, p.29) yaitu: mengingat (remembering), memahami (understanding), menerapkan (applying), menganalisis (analysing), menilai (evaluating), dan mencipta (creating). Perubahan tingkat kognitif digambarkan sebagai berikut.

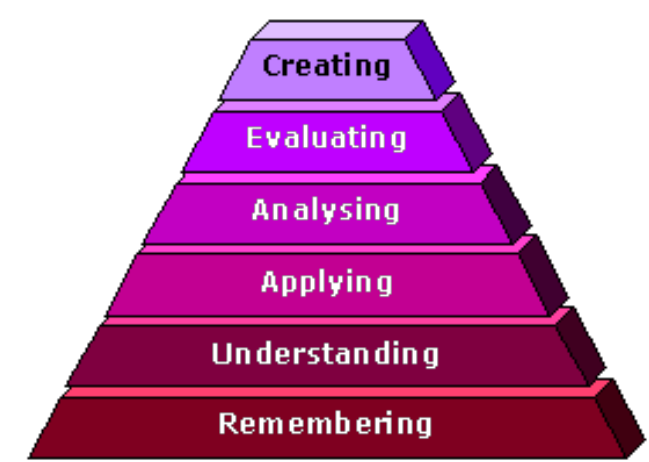

Gambar 2. Perbaikan Kompetensi Kognitif Sumber: Atherton (2013) 
Ranah psikomotor merupakan taksonomi belajar Bloom yang terfokus pada keterampilan yang berkaitan dengan tugas motorik. Pada dasarnya ranah psikomotor merupakan standar pembelajaran sesuai kebutuhan industri. Ranah psikomotor akan dijelaskan dalam 4 pandangan taksonomi. Taksonomi Simpon's dengan perkembangan penguasaan berdasarkan penemuan pengamatan meliputi: persepsi (perception), keteraturan (set), respons terbimbing (guided response), mekanisme (mechanism), respons cepat (complex overt response), adaptasi (adaptation), dan inisiasi (origination). Taksonomi Dave's terfokus pada kemampuan fisik, meliputi: imitasi (imitation), manipulasi (manipulation), presisi (precision), artikulasi (articulation), dan naturalisasi (naturalization). Taksonomi Harrow's dengan perkembangan penguasaan terlatih pada anak, meliputi: gerakan refleks (reflex movements), gerakan fundamental dasar (basic fundamental movements), kemampuan mengamati (perceptual), kemampuan fisik (physical activities), gerakan keterampilan (skilled movements), dan kemampuan komunikasi non-diskursif (non-discursive communication). Taksonomi dengan kategori herarkis sensorik, fisik, tugas psikomotor dan keterampilan, di tempat kerja atau industri, taksonomi ini digunakan untuk syarat membangun kemampuan, tetapi tidak sesuai dengan pengelompokan hasil belajar.

Leighbody dan Kidds (1968, p.38) menjelaskan bahwa keterampilan yang dilatih melalui praktik secara berulang-ulang akan menjadi kebiasaan yang otomatis. Dalam proses pembelajaran keterampilan, keselamatan kerja tidak boleh diabaikan. Keselamatan meliputi: peserta, bahan, dan alat. Keselamatan kerja dan proses pembelajaran psikomotor tidak dapat dipisahkan, keduanya merupakan bagian dari penilaian hasil keterampilan. Hasil penilaian mencakup: (1) penggunaan alat dan sikap kerja; (2) kemampuan menganalisis suatu pekerjaan serta menyusun urutan-urutan pekerjaan; (3) kecepatan mengerjakan tugas; (4) kemampuan membaca gambar dan simbol; dan (5) keserasian bentuk dengan yang diharapkan.

Ranah afektif dilatar belakangi oleh rumusan pancasila dan pembukaan UUD 1945 terkait realita berkembangnya permasalahan bangsa sejauh ini. UU tahun 2003 Nomor 20 tentang Sistem Pendidikan Nasional yang inti dari pernyataan tersebut, yaitu: "Mewujudkan masyarakat berakhlak mulia, bermoral, beretika, berbudaya, dan beradap berdasarkan falsafah pancasila". Atas dasar amanat tersebut pendidikan afektif bukan hanya sekedar mengajarkan mana yang benar dan mana yang salah. Sesuai dengan yang diungkapkan Abdulloh Hamid \& Putu Sudira (2013, p.39), menyatakan bahwa "Pendidikan karakter menanamkan kebiasaan (habitutation) tentang hal mana yang baik, sehingga peserta didik menjadi paham (kognitif) tentang mana yang benar dan yang salah, mampu merasakan (afektif) nilai yang baik dan bisa melakukannya (psikomotor)".

Menurut Wina Sanjaya (2010, p.40) menyatakan bahwa "Sikap merupakan refleksi dari nilai yang dimiliki, oleh karenanya pendidikan sikap pada dasarnya pendidikan nilai". Tahapan ranah sikap dijelaskan dalam Thomas (2004, p.40), Madya, Aka \& J. J (2009, p.40), dan Miftakhul Huda (2014, P.40), sebagai berikut: menerima (recaiving), merespons (responding), menghargai (valuating), mengatur (organizing), dan berkarakter (characterization). Tahapan aspek afektif digambarkan sebagai berikut.

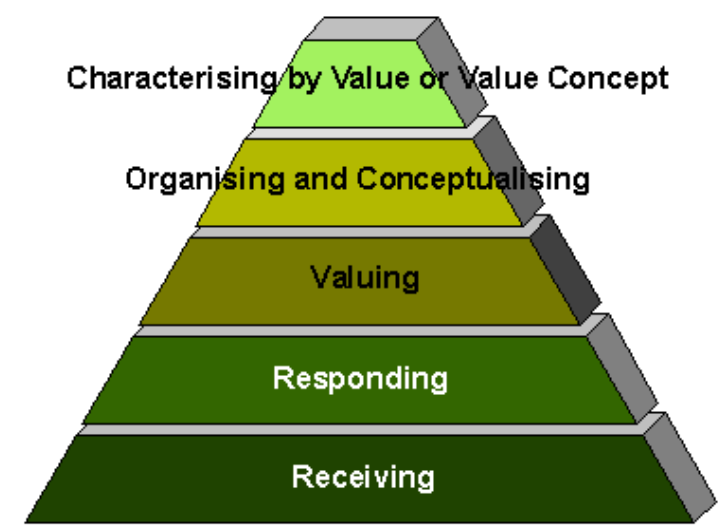

Gambar 3. Affective Domain Sumber: Atherton (2013)

\section{Metode Problem-Based Learning}

Warsono \& Hariyanto (2013, p.45), mengungkapkan "Model merupakan langkahlangkah pembelajaran dengan sintaks sudah ditentukan lain halnya metode pembelajaran guru diberikan kekuasaan dalam memvariasi”. 
Endang Mulyatiningsih (2010, p.45), bahwa metode pembelajaran merupakan istilah yang digunakan untuk menggambarkan proses belajar mengajar dari awal sampai akhir. Pembelajaran sistem pengapian konvensional mengimplementasikan metode problem-based learning.

Problem-based learning merupakan pendekatan kontekstual, yang berpusat pada siswa, sesuai ungkapan Namedo (2012, p.45), "Problem-based learning it is a student centered, contextualized learning". Permasalahan yang diterapkan adalah permasalahan yang komplek pada dunia nyata dan tidak terstruktur. Permasalahan diselesaikan secara tim kecil dengan keahlian kolektif untuk mengakuisi, berkomunikasi, dan mengintegrasikan komunikasi secara tim, sesuai ungkapan Dondlinger \& McLeot (2015, p.47), The team level characteristics include: (1) facilitator effectiveness; (2) team autonomy; (3) diversity; and (4) learning team collaboration".

Fogarty (1997, p.48) dan Tan (2004, p.48), menjelaskan karakteristik dari problem-based learning meliputi: (1) meet the problem;, (2) define the problem; (3) gather the fact; (4) generate questions; (5) make hypotheses; (6) rephrase the problem; (7) generate alternative solutions; dan (8) present the solutions, preferably with justifications. Karakteristik tersebut menunjukkan penemuan masalah sampai ditemukan solusi dari permasalahan tersebut.

Langkah-langkah Pelaksanaan Pembelajaran diungkapkan Sharma (2012, p.50) bahwa tahapan problem-based learning yaitu: (a) orienting students to the problems; (b) organising students for study; (c) assisting independent and group investigation; (d) developing and presenting reports, videos, models etc. and (e) analysing and evaluating the problem solving process.

\section{Peran Problem-Based Learning}

Arends (2008, p.57) bahwa "Problembased learning mendukung pemikiran tingkat tinggi dalam situasi berorientasi masalah". Keterlaksanaan pemikiran tingkat tinggi tidak lepas dari peran seorang guru. Peran guru dalam pelaksanaan problem-based learning adalah mempresentasikan ide-ide atau mendemontrasikan berbagai keterampilan dengan cara menyodorkan berbagai masalah autentik, memfasilitasi penyelidikan siswa, dan mendukung pembelajaran siswa. sehingga, peran guru mampu meningkatkan hasil belajar siswa, karena siswa tidak mampu terlepas dari bantuan guru. Adapun peran guru dalam menerapakan problem-based learning dapat meningkatkan hasil belajar meliputi aspek kognitif, psikomotor, dan afektif.

Peran problem-based learning dalam aspek kognitif, diungkapkan Masek \& Yamin (2011, p.57), bahwa "In theory, the PBL method is believed to create an environment that conductive for deep content learning, which in believed to affect students ability to apply knowledge". Sejalan dengan Tan (2009, P.58) bahwa problem-based learning berkontribusi terhadap aspek kognitif.

Peran problem-based learning dalam aspek psikomotor, diungkapkan Savery \& Dufy (2001, p.59) menjelaskan hubungan antara teori dan praktik dalam lingkungan problembased learning siswa terlihat aktif bekerja sesuai dengan tugas dan kegiatan otentik. Fokusnya mengkonstruksi pengetahuan dan mengaplikasikannya dalam keterampilan.

Peran problem-based learning dalam aspek afektif, diungkapkan Hande, Muhammed, \& Kommatil (2014, p.62), "Problem-based learning in small groups provided students with a favourable, safe environment for developing the necessary skills and attitudes". Sehingga, pendidikan perlu ditelaah lebih lanjut pentingnya keberadaan kemampuan sikap untuk menjadi individu yang pinter, bener, dan pener.

\section{Kompetensi Sistem Pengapian Konvensional}

Kompetensi dasar sistem pengapian konvensional merupakan salah satu bagian dari mata pelajaran perbaikan kelistrikan kendaraan ringan (PKKR) yang harus dikuasai oleh siswa paket keahlian teknik kendaraan ringan (TKR). Dalam pokok bahasan ini peserta didik harus menguasai kompetensi dasar sebagai berikut: (1) mendeskripsikan fungsi dan komponen-komponen sistem pengapian konvensional; (2) mendeskripsikan 
Tabel 2. Tahap Pelaksanaan Problem-Based Learning

\begin{tabular}{|c|c|}
\hline Tahapan $P B L$ & Aktivitas Guru dan Siswa \\
\hline $\begin{array}{c}\text { Fase } 1 \\
\text { Memberikan orientasi } \\
\text { tentang permasalahan } \\
\text { kepada siswa }\end{array}$ & $\begin{array}{l}\text { a. Guru menjelaskan tujuan pembelajaran materi sistem pengapian } \\
\text { dengan metode problem-based learning. } \\
\text { b. Guru menjelaskan tahapan dalam problem-based learning. } \\
\text { c. Guru mendeskripsikan perangkat yang dibutuhkan dalam problem- } \\
\text { based learning. } \\
\text { d. Guru memotivasi siswa untuk terlibat dalam mengatasi masalah }\end{array}$ \\
\hline $\begin{array}{l}\text { Fase } 2 \\
\text { Mengorganisasikan } \\
\text { siswa untuk meneliti }\end{array}$ & $\begin{array}{l}\text { a. Guru membagi siswa menjadi kelompok kecil untuk melaksanakan } \\
\text { eksperimen } \\
\text { b. Guru mendorong siswa untuk mengidentifikasi tugas-tugas belajar } \\
\text { terkait permasalahan }\end{array}$ \\
\hline $\begin{array}{c}\text { Fase } 3 \\
\text { Membantu investigasi } \\
\text { mandiri dan kelompok }\end{array}$ & $\begin{array}{l}\text { a. Guru mendorong siswa untuk mendapatkan informasi yang tepat } \\
\text { berkaitan dengan sistem pengapian } \\
\text { b. Guru mendorong siswa melaksanakan eksperimen perbaikan } \\
\text { sistem pengapian } \\
\text { c. Guru mendorong siswa untuk mencari penjelasan dan solusi dari } \\
\text { permasalahan sistem pengapian yang ditemukan }\end{array}$ \\
\hline $\begin{array}{c}\text { Fase } 4 \\
\text { Mengembangkan dan } \\
\text { menyajikan hasil karya }\end{array}$ & $\begin{array}{l}\text { Guru membantu siswa merencanakan dan menyiapkan laporan hasil } \\
\text { eksperimen sistem pengapian dan mempersiapkan presentasi }\end{array}$ \\
\hline $\begin{array}{l}\text { Fase } 5 \\
\text { Menganalisis dan } \\
\text { mengevaluasi proses } \\
\text { pemecahan masalah }\end{array}$ & $\begin{array}{l}\text { Guru membantu siswa untuk melakukan refleksi terhadap investigasi } \\
\text { dan proses-proses yang telah digunakan }\end{array}$ \\
\hline
\end{tabular}

cara kerja dan prinsip kerja sistem pengapian konvensional; (3) Mendiskripsikan saat pengapian; (4) mendeskripsikan komponen dan cara kerja advans sentrifugal dan advans vacum; (5) melakukan pemeriksaan perbaikan, penyetelan, dan penggantian rangkaian primer pada sistem pengapian konvensional; (6) melakukan pemeriksaan dan penggantian kontak pemutus; (7) melakukan pemeriksaan komponen-komponen pengapian; (8) melakukan penyetelan saat pengapian; dan (9) pemeriksaan fungsi advans sentrifugal dan advans vacum.

\section{METODE PENELITIAN}

\section{Jenis Penelitian}

Jenis penelitian yang digunakan adalah classroom action research atau sering dikenal dengan istilah penelitian tindakan kelas, dengan tujuan memperbaiki kualitas pembelajaran dan profesionalisme guru.
Penelitian tindakan kelas dilakukan dengan beberapa siklus dengan setiap siklusnya terdiri dari 4 tahapan yaitu: perencanaan (plainning), tindakan (action), pengamatan (observing), dan refleksi (reflecting), Mctaggart (1991, p.70) dan Kemmis \& McTaggart (1988, p.70).

\section{Waktu dan Tempat Penelitian}

Penelitian ini dilakukan di SMK Ma'arif Salam yang berlokasi di jalan Magelang Km. 20, Citrogaten, Salam, Magelang. Waktu penelitian dilaksanakan pada semester gasal tahun pelajaran 2014/2015 tepatnya pada bulan Januari-Februari 2015.

\section{Subjek dan Karakteristiknya}

Subjek penelitian ini adalah siswa kelas XI OB yang berjumlah 39 siswa, dengan karakteristik siswa berdasarkan pengamatan dan masukan arahan guru selama pelaksanaan pembelajaran sulit dikondisikan dan nilai praktik yang diperoleh lebih rendah dibandingkan kelas yang lain. 


\section{Skenario Tindakan}

Pelaksanaan tindakan berkolaborasi antara guru sebagai pihak pelaku tindakan dan kolaborator sebagai pengamat perubahan tindakan. Tahap perencanaan tindakan direncanakan berdasarkan refleksi awal dari hasil observasi lapangan. Kegiatan yang dilakukan meliputi: (1) mempersiapkan jadwal pelaksanaan, (2) mempersiapkan RPP, (3) mempersiapkan perangkat problem-based learning, (4) mempersiapkan alat dan bahan yang dipergunakan dalam eksperimen, (5) mengelompokkan siswa, dan (6) mensosialisasi metode problem-based learning.

Tahap pelaksanaan tindakan menggunakan metode problem-based learning terdiri dari 5 fase yang dirinci dalam keaktifan guru dan siswa ditunjukkan pada tabel 2 .

Tahap pelaksanaan tindakan merupakan pengaplikasian dari rencana pelaksanaan pembelajaran yang dibagi menjadi kegiatan pendahuluan, kegiatan inti, dan kegiatan penutup. Kegiatan pendahuluan meliputi: pengerjaan pretest, penjelasan materi singkat, pemaparan permasalahan, tujuan pembelajaran dan motivasi, dan pembagian kelompok. Kegiatan inti meliputi: mengingatkan tahapan penyelesaian masalah, mengorganisasi siswa mencari solusi, membimbing perencanaan eksperimen, membimbing identifikasi masalah dan mengumpulkan informasi, membimbing melakukan eksperimen, menganalisa, dan mengevaluasi hasil, menyusun laporan eksperimen, menganalisa dan mengevaluasi proses pemecahan masalah. Kegiatan penutup meliputi: menyampaikan hasil diskusi dan melakukan penilaian hasil belajar aspek kognitif, aspek psikomotor, dan aspek afektif siswa.

\section{Teknik dan Instrumen Pengumpulan Data}

Data penelitian ini berbentuk kuantitatif yang dianalisis secara deskriptif, diukur menggunakan instrumen sebagai berikut.

Pertama, kuesioner keaktifan guru dan siswa yang digunakan untuk mengetahui peningkatan keaktifan pelaksanaan pembelajaran berbasis problem-based learning. Instrumen yang digunakan berupa checklist.

Kedua, tes hasil belajar siswa berupa aspek kognitif, psikomotor, dan afektif yang digunakan untuk meningkatkan hasil belajar siswa. Tes hasil belajar dilaksanakan 2 siklus.

Instrumen aspek kognitif yang digunakan berupa lembar soal tes dalam bentuk pilihan ganda dengan 4 alternatif jawaban. Jawaban benar diberi skor 1 dan jawaban salah diberi skor 0. Jumlah soal tes pada siklus I dan II masing-masing yaitu 45 soal dan 40 soal. Indikator aspek kognitif berupa: mengingat, memahami, menerapkan, menganalisis, mengevaluasi, dan mencipta.

Instrumen aspek psikomotor yang digunakan berupa lembar unjuk kerja dengan bentuk penilaian rating scale $(0,1,2$, dan 3$)$ yang disertai rubrik penilaian. Bobot indikator penilaian psikomotor meliputi: persiapan kerja $(15 \%)$, proses kerja $(35 \%)$, hasil kerja $(30 \%)$, sikap kerja (10\%), dan waktu kerja (10\%).

Instrumen aspek afektif dilakukan 2 penilaian berupa penilaian diri dan penilaian antar teman. Instrumen penilaian diri yang digunakan berupa lembar sikap dengan bentuk penilaian checklist dalam bentuk skala likert dengan alternatif jawaban 5 yaitu: sangat sering melakukan (SS), sering melakukan (SM), jarang melakukan (JM), pernah melakukan (PM), dan tidak melakukan sama sekali (TM). Instrumen penilaian antar teman berupa lembar sikap dengan bentuk penilaian rating scale $(1,2,3$, dan 4) yang disertai rubrik penilaian. Bobot indikator penilaian diri dikalikan 1 dan anata teman dikalikan 2 kemudian direrata. Indikator penilaian afektif yang digunakan yaitu: menghargai dan menghayati agama, kejujuran, toleransi, sopan dan santun, percaya diri, kedisiplinan, tanggungjawab, dan kerjasama/gotong royong.

\section{Keberhasilan dan Teknik Analisis Data}

Keberhasilan tindakan ditentukan dengan membandingkan hasil tindakan dengan indikator keberhasilan yang ditentukan. Indikator keberhasilan dari keaktifan pelaksanaan pembelajaran yaitu seluruh siswa pada kategori tinggi dan indikator keberhasilan hasil belajar aspek kognitif, psikomotor, dan afektif yaitu $80 \%$ siswa pada kategori tinggi dengan kompetensi minimal yang dicapai siswa yaitu 70,0 . 
Data kuantitatif yang diperoleh kemudian dianalisis. Menurut Pardjono, dkk. (2007, p.94) "Teknik statistikyang digunakan adalah statistik deskriptif”. Dianalisis dengan menyajikan data prosentase dan ditarik kesimpulan berdasarkan indikator sesuai kriteria yang ditentukan dalam Djemari Mardapi (2008, p.94), sebagai berikut.

Tabel 3. Kriteria Ketuntasan

\begin{tabular}{ll}
\hline Skor Siswa & Kategori \\
\hline$X \geq \mu+1 . S B x$ & Sangat Tinggi \\
$\mu+1 . S B x>X \geq \mu$ & Tinggi \\
$\mu>X \geq \mu-1 . S B x$ & Rendah \\
$X<\mu-1 . S B x$ & Sangat Rendah \\
\hline
\end{tabular}

Keterangan:

$\mu=$ median ideal $=1 / 2$ (skor tertinggi ideal + skor terendah ideal)

$\mathrm{X}=$ skor responden

$\mathrm{SB}=$ simpangan baku ideal $=1 / 6$ (skor tertinggi ideal - skor terendah ideal)

\section{HASIL PENELITIAN DAN PEMBAHASAN}

\section{Keterlaksanaan Keaktifan Problem-Based Learning}

Keaktifan guru pada siklus I dan siklus II, keduanya memperoleh skor 16 (100\%) dari skor maksimal 16. Kriteria kategori keaktifan guru yaitu sangat tinggi dalam menerapkan pembelajaran berbasis problem-based learning pada kompetensi dasar sistem pengapian konvensional. Artinya keaktifan guru telah berjalan sesuai perencanaan.

Keaktifan siswa pada siklus I dan siklus II masing-masing memperoleh skor 75,3\% dan $84,4 \%$. Data peningkatan keaktifan siswa dapat dilihat pada tabel 4 dan tabel 5 .

Keaktifan siswa dalam pelaksanaan problem-based learning terdiri dari 7 indikator. Pada siklus I dari 7 indikator tersebut, 4 diantaranya belum mencapai kategori, yaitu: mencari informasi yang tepat,

Tabel 4. Keaktifan Siswa Siklus I dan Siklus II

\begin{tabular}{lcc}
\hline Indikator Keaktifan Siswa & Siklus I & Siklus II \\
\hline Belajar kelompok. & $97,44 \%$ & $97,44 \%$ \\
Bekerjasama mendefinisikan permasalahan & $83,33 \%$ & $85,90 \%$ \\
Terlibat dalam eksperimen & $89,74 \%$ & $89,74 \%$ \\
Mencari informasi yang tepat. & $61,54 \%$ & $76,92 \%$ \\
Membuat kesimpulan. & $62,82 \%$ & $73,08 \%$ \\
Mempersiapkan laporan dan presentasi. & $66,67 \%$ & $87,18 \%$ \\
Mempersiapkan hasil eksperiment. & $64,10 \%$ & $97,44 \%$ \\
Jumlah Rerata & $75,3 \%$ & $84,4 \%$ \\
\hline
\end{tabular}

Tabel 5. Peningkatan Kategori Keaktifan Siswa

\begin{tabular}{llll}
\hline \multirow{2}{*}{ Skor Siswa } & \multicolumn{2}{c}{ Kategori } & \multicolumn{2}{c}{ Frekuensi } \\
\cline { 3 - 4 } & Sangat tinggi & 30 & 36 \\
$\mathrm{X} \geq 6,8$ & Tinggi & 7 & 3 \\
$6,7>\mathrm{X} \geq 5,1$ & Rendah & 2 & 0 \\
$5>\mathrm{X} \geq 3,4$ & Sangat rendah & 0 & 0 \\
$\mathrm{X}<3,3$ & & 39 & 39 \\
Total & & & \multicolumn{2}{c}{ II } \\
\hline
\end{tabular}


membuat kesimpulan, mempersiapkan laporan dan presentasi, dan mempersiapkan hasil eksperimen. Kondisitersebutdisebabkan bahwa sebelumnya problem-based learning belum pernah diterapkan sama sekali serta materi sistem pengapian baru pertama kali diajarkan. Hasil pengamatan menunjukkan bahwa siswa belum menggunakan sumber referensi buku dan ketersediaan sarana prasarana internet dengan baik. Hasil identifikasi terhadap permasalahan tersebut menjadikan siswa kebingungan dalam menghubungkan terjadinya kerusakan dan perbaikan yang dilakukan. Pembuatan laporan hasil eksperimen masih mengalami kesulitan terutama apa saja yang akan disampaikan dalam presentasi belum terkoordinasi dengan jelas terutama pada pembagian tugas, sehingga siswa terlihat pasif tanpa peran. Saat diskusi berlangsung siswa dalam mengemukakan pendapat terlihat pasif dibuktikan adanya sejumlah pertanyaan yang dilakukan pada siswa yang sama.

Data keaktifan siswa yang diperoleh diklasifikasikan kedalam kategori perolehan. Skor keaktifan siswa dalam problem-based learning pada kategori sangat tinggi sebanyak 30 siswa $(76,9 \%)$, kategori tinggi sebanyak 7 siswa $(17,9 \%)$ dan kategori rendah sebanyak 2 siswa $(5,2 \%)$. Target keberhasilan yang telah ditentukan adalah seluruh siswa pada kategori tinggi. Pada siklus I masih terdapat 2 siswa yang belum mencapai target keberhasilan, sehingga keaktifan siswa ditingkatkan pada siklus II.

Hasil keaktifan siswa pelaksanaan problem-based learning siklus II menunjukkan peningkatan yang lebih baik. Indikator keaktifan siswa yang belum terpenuhi pada siklus I mengalami peningkatan yang baik. Ketercapaian pada siklus II memperoleh prosentase keberhasilan sebasar $84,4 \%$, dengan kategori keberhasilan yang diperoleh yaitu kategori sangat tinggi sebanyak 36 siswa $(92,3 \%)$ dan kategori tinggi sebanyak 3 siswa $(7,7 \%)$.

\section{Hasil Belajar Menerapkan Problem-Based Learning}

Sebelum penelitian tindakan dilakukan, langkah pertama yang dilakukan adalah menguji kemampuan awal siswa dengan cara memberikan pretest untuk memperoleh data awal. Selanjutnya dilakukan data yang diperoleh dibandingkan dengan postest untuk melihat peningkatan pada setiap siklusnya. Peningkatan hasil belajar yang peroleh untuk mengetahui penguasaan pembelajaran setiap siklus. Data hasil pretest siklus I dan siklus II dapat dilihat sebagai berikut.

Tabel 6. Hasil Pretest Siklus I dan Siklus II

\begin{tabular}{lcc}
\hline \multirow{2}{*}{$\begin{array}{l}\text { Indikator Hasil } \\
\text { Belajar Kognitif }\end{array}$} & \multicolumn{2}{c}{ Hasil Pretest } \\
\cline { 2 - 3 } & Siklus I & Siklus II \\
\hline Mengingat & $58,97 \%$ & $82,69 \%$ \\
Memahami & $65,93 \%$ & $66,15 \%$ \\
Menerapkan & $59,21 \%$ & $63,53 \%$ \\
Menganalisa & $61,54 \%$ & $71,79 \%$ \\
Menilai & $58,33 \%$ & $70,26 \%$ \\
Mencipta & $55,13 \%$ & $71,79 \%$ \\
Jumlah Rerata & $59,85 \%$ & $71,04 \%$ \\
\hline
\end{tabular}

Tindakan yang dilakukan setelah melaksanakan keaktifan guru dan siswa menerapkan metode problem-based learning, yaitu mengukur keberhasilan siswa terhadap pembelajaran yang telah dilaksanakan. Pengukuran hasil belajar yang dilakukan meliputi: aspek kognitif, aspek psikomotor, dan aspek sikap. Tes hasil belajar dilaksanakan 2 siklus yaitu siklus I dan siklus II. Adapun hasil belajar yang diperoleh setelah menerapkan metode problem-based learning sebagai berikut.

Tabel 7. Hasil Belajar Aspek Kognitif

\begin{tabular}{lcc}
\hline \multirow{2}{*}{$\begin{array}{l}\text { Indikator Hasil } \\
\text { Belajar Kognitif }\end{array}$} & \multicolumn{2}{c}{ Hasil Postest } \\
\cline { 2 - 3 } & Siklus I & Siklus II \\
\hline Mengingat & $76,41 \%$ & $87,82 \%$ \\
Memahami & $82,42 \%$ & $78,97 \%$ \\
Menerapkan & $71,56 \%$ & $79,77 \%$ \\
Menganalisa & $77,29 \%$ & $79,91 \%$ \\
Menilai & $74,36 \%$ & $79,97 \%$ \\
Mencipta & $71,15 \%$ & $78,46 \%$ \\
Jumlah Rerata & $75,33 \%$ & $80,65 \%$ \\
\hline
\end{tabular}

Hasil belajar aspek kognitif postest siklus I sebesar 75,33\%, mengalami peningkatan 
sebesar $15,68 \%$ dari pretest siklus I sebesar $59,85 \%$. Berdasarkan angka tersebut, dari 39 siswa ketuntasan hasil belajar di atas kompetensi minimal yaitu 70,0 sebanyak $76,9 \%$ (30 siswa). Indikator keberhasilan hasil belajar aspek kognitif adalah $80 \%$ siswa tuntas di atas kompetensi. Sehingga, hasil belajar aspek kognitif siklus I belum tercapai.

Mempertimbangkan hasil belajar aspek kognitif tersebut guru memberikan tindakan berupa: (1) penjelasan kepada siswa bahwa setiap tujuan pembelajaran perlu dilakukan bagi siswa yang masih terkesan pasif, dan (2) meminta agar koordinator kelompok mengkondisikan anggotanya ikut serta dalam pelaksanaan pencapaian tujuan pembelajaran. Guru dan kolaborator juga memotivasi siswa yang tidak terlibat aktif dalam pelaksanaan tindakan menerapkan pembelajaran berbasis problem-based learning pada kompetensi dasar sistem pengapian konvensional.

Hasil belajar aspek kognitif postest siklus II sebesar 80,65\% mengalami kenaikan sebesar $9,61 \%$ dari pretest siklus II sebesar 71,04\%. Berdasarkan angka tersebut, dari 39 siswa ketuntasan hasil belajar di atas kompetensi minimal yaitu 70,0 sebanyak 92,3\% (36 siswa). Indikator keberhasilan hasil belajar aspek kognitif adalah $80 \%$ siswa tuntas di atas kompetensi. Sehingga, hasil belajar aspek kognitif siklus II telah tercapai. Peningkatan hasil aspek kognitif sebesar 5,32\%.

Setelah pelaksanaan tes aspek kognitif selanjutnya dilakukan tes aspek psikomotor yang dilakukan secara individu. Adapun hasil belajar aspek psikomotor sebagai berikut.

Tabel 8. Hasil Belajar Aspek Psikomotor

\begin{tabular}{lcc}
\hline Indikator Psikomotor & Siklus I & Siklus II \\
\hline Persiapan kerja & $84,30 \%$ & $92,60 \%$ \\
Proses kerja & $77,00 \%$ & $83,80 \%$ \\
Hasil kerja & $74,10 \%$ & $84,20 \%$ \\
Sikap kerja & $86,30 \%$ & $88,70 \%$ \\
Waktu & $78,60 \%$ & $81,20 \%$ \\
Total & $80,57 \%$ & $85,63 \%$ \\
\hline
\end{tabular}

Hasil belajar aspek psikomotor siklus I diperoleh prosentase yaitu $80,57 \%$. Berdasarkan prosentase tersebut, dari 39 siswa ketuntasan hasil belajar diatas kompetensi minimal yaitu 70,0 sebanyak $82,0 \%$ (32 siswa). indikator keberhasilan aspek psikomotor adalah $80 \%$ siswa tuntas di atas kompetensi. Sehingga, hasil belajar aspek psikomotor siklus I telah tercapai, namun karena siklus II masih dilaksanakan maka tes psikomotor dilakukan sekaligus melihat peningkatan pada siklus selanjutnya.

Hasil belajar aspek psikomotor siklus II diprosentase yaitu $85,63 \%$. Berdasarkan prosentase tersebut, dari 39 siswa ketuntasan hasil belajar diatas kompetensi minimal yaitu 70,0 sebanyak 92,31\% (36 siswa). indikator keberhasilan aspek psikomotor adalah 80\% siswa tuntas di atas kompetensi. Sehingga, hasil belajar aspek psikomotor siklus II telah tercapai, peningkatan hasil belajar aspek psikomotor sebesar 5,03\%.

Tes yang terakhir dilakukan yaitu tes aspek afektif siswa yang meliputi penilaian diri sendiri dan penilaian antar teman, dengan indikator yang ditentukan sebanyak 8 . Adapun hasil belajar aspek afektif sebagai berikut.

Tabel 9. Hasil Belajar Aspek Afektif

\begin{tabular}{lcc}
\hline Indikator Afektif & Siklus I & Siklus II \\
\hline Menghargai agama & $77,20 \%$ & $80,80 \%$ \\
Kejujuran & $72,30 \%$ & $75,60 \%$ \\
Toleransi & $79,40 \%$ & $81,20 \%$ \\
Sopan/ santun & $76,70 \%$ & $78,10 \%$ \\
Percaya diri & $70,40 \%$ & $74,10 \%$ \\
Kedisiplinan & $79,50 \%$ & $80,70 \%$ \\
Tanggungjawab & $74,40 \%$ & $76,90 \%$ \\
Kerjasama & $78,50 \%$ & $80,90 \%$ \\
Total & $76,00 \%$ & $78,54 \%$ \\
\hline
\end{tabular}

Hasil belajar aspek afektif siklus I diperoleh prosentase yaitu $76,0 \%$. Berdasarkan prosentase tersebut, dari 39 siswa ketuntasan hasil belajar di atas kompetensi minimal yaitu 70,0 sebanyak $72,0 \%$ (28 siswa). indikator keberhasilan aspek afektif adalah $80 \%$ siswa tuntas di atas kompetensi. Sehingga, hasil belajar aspek afektif siklus I belum tercapai,

Hasil belajar aspek afektif siklus II diprosentase yaitu 78,5\%. Berdasarkan prosentase tersebut, dari 39 siswa ketuntasan hasil belajar diatas kompetensi minimal yaitu 
70,0 sebanyak 97,4\% (39 siswa). indikator keberhasilan aspek psikomotor adalah $80 \%$ siswa tuntas di atas kompetensi. Sehingga, hasil belajar aspek afektif siklus II telah tercapai, peningkatan hasil belajar aspek psikomotor sebesar $2,05 \%$.

\section{SIMPULAN DAN SARAN}

\section{Simpulan}

Keaktifan siswa meningkat sebesar $11,72 \%$ dengan menerapkan pembelajaran berbasis problem-based learning pada siswa SMK Ma'arif Salam pada kompetensi dasar sistem pengapian konvensional.

Keaktifan siswa meningkat pada siklus I sebesar 75,09\% dan siklus II sebesar $86,81 \%$ dengan kategori sangat tinggi sebanyak 36 siswa dan kategori tinggi sebanyak 3 siswa setelah menerapkan pembelajaran berbasis problem-based learning pada siswa SMK Ma'arif Salam pada kompetensi dasar sistem pengapian konvensional.

Peningkatan hasil belajar aspek kognitif setelah menerapkan $P B L$ sebesar 5,32\% dengan tingkat kemampuan aspek kognitif yaitu: mengingat sebesar $87,82 \%$, memahami sebesar 78,97\%, menerapkan sebesar 79,77\%, menganalisa sebesar $79,91 \%$, menilai sebesar $78,97 \%$, dan mencipta sebesar 78,46\%; peningkatan hasil belajar aspek psikomotor sebesar 5,03\% dengan indikator kemampuan aspek psikomotor yaitu: persiapan kerja sebesar $92,6 \%$, proses kerja sebesar $83,8 \%$, hasil kerja sebesar $84,2 \%$, sikap kerja sebesar $86,3 \%$, dan waktu sebesar $81,2 \%$; dan peningkatan hasil belajar aspek afektif sebesar 2,05\% dengan indikator kemampuan aspek afektif yaitu: menghargai dan menghayati agama sebesar $80,8 \%$, kejujuran sebesar $75,6 \%$, toleransi sebesar $81,2 \%$, sopan/santun sebesar $78,1 \%$, percaya diri sebesar $74,1 \%$, kedisiplinan sebesar $80,7 \%$, tanggungjawab sebesar $76,9 \%$, dan kerja sama/gotong royong sebesar $80,9 \%$.

Jumlah siswa yang mencapai kompetensi minimal pada hasil belajar aspek kognitif sebanyak 36 siswa $(92,31 \%)$, hasil belajar aspek psikomotor sebanyak 36 siswa (92,31\%), dan hasil belajar aspek afektif sebanyak 38 siswa dari 39 siswa $(97,40 \%)$ setelah penerapan problem-based learning.

\section{Saran}

Bagi guru, (1) apabila guru meningkatkan keaktifan dan hasil belajar siswa dengan pembelajaran problem-based learning sebaiknya membuat perencanaan, persiapan, dan waktu yang cukup serta pemilihan materi pembelajaran yang tepat. (2) sebaiknya guru membuat panduan tertulis dalam pelaksanaan problem-based learning, sehingga lebih mudah mensosialisasikan kepada siswa dan siswa dapat mempelajari terlebih dahulu.

Bagi sekolah, penggunaan problembased learning dapat meningkatkan keaktifan dan hasil belajar siswa, sehingga guru dapat menggunakan metode problem-based learning, sesuai dengan karakteristik dari materi yang diajarkan.

Bagi peneliti, diharapkan dapat melakukan penelitian dengan menerapkan metode problem-based learning pada mata pelajaran yang lain dan lebih banyak menggunakan subjek penelitian, sehingga hasilnya lebih luas dan memungkinkan untuk digeneralisasikan.

\section{DAFTAR PUSTAKA}

Abdulloh Hamid \& Putu Sudira. (2013). Penanaman nilai-nilai karakter siswa smk salafiyah prodi tkj kajen margoyoso pati jawa tengah. Jurnal Pendidikan Vokasi, Vol. 3, No. 2, 138-152.

Anderson, L. W. \& Krathwohl, D. R. (2001). A taxonomy for learning teaching and assessment: a revision af bloom's taxonomy of education objectives. New York, San Fransisko, Boston: Addison Wesley Longman, Inc.

Arends, R. I. (2008). Belajar untuk mengajar. (Terjemahan Helly Prajitno Soetjipto \& Sri Mulyantini Soetjipto). New York: McGraw Hills. (Buku asli diterbitkan tahun 2007).

Bloom, B.S (ed). (1956). Taxonomy of educational objective: the clasification of educational goals. Handbook I cognitive domain. New York: David McKay Company. 
Brown, A., Kirpal, S., \& Rauner, F. (2007). Identitas at work. Dordrecht: Springer.

Djemari Mardapi. (2008). Teknik penyusunan instrumen tes dan non tes. Yogyakarta: Mitra Cendekia Press.

Donlinger, M. J. \& McLeod, J. K. (2015). Solving real world problems with alternate reality gaming: student experiences in the globalvillage playground capstone course design. Interdiciplinary Journal of ProblemBased Learning, Vol. 9 (2). No. 15415014.

Endang Mulyatiningsih. (2010, Agustus). Pembelajaran aktif, kreatif, inovatif, efektif dan menyenangkan (paikem). Makalah disajikan dalam Diklat Peningkatan Kompetensi Pengawas dalam Rangka Penjamin Mutu Pendidikan, di P4TK Bisnis dan Pariwisata.

Fogarty, R. (1997). Problem learning \& other curiculum models for the multiple intelligences clasroom. SkyLight: Pearson.

Hande, S., Mohammed, C. A., \& Komattil, R. (2014). Acquisition of knowledge, generik skill and attitudes through problem-based learning: student perspectives of a hybrid curriculum. Journal of Taibah University Medical Sciences, 1-5.

Huitt, W. (2011). Bloom et al.'s taxonomy of the cognitive domain. Voldosta, GA: Voldosta State University. Diakses pada tanggal 18 Agustus 2014 dalam http:// www.edpsycinteractive.org /topics/ cogsys/bloom.html [pdf].

Kemmis, S. \& McTaggart, R. (1988). The action research planner. Victoria; Deakin University Press.

Leighbody, G. B., \& Kidd, D. M. (1968). Methods of teaching shop and technical subject. New York: Delmar Publishers.
Madya, Aka. J. J., \& J. J. (2009). A brief guide to learning domains (cognitive, pshychomotor, \& affective) life skill. Selangor, Malaysia: OBE-LOKI Workshop FSG.

Masek, A., \& Yamin, S. (2011). Problem based learning for epistemological competence: the knowledge acquisition perspective. Journal of Techical Education and Training (JTET), Vol. 3, No. 1, 29-26.

McTaggart, R. (1991). Action research a short modern history. Victoria: Deakin University Press.

Miftahul Huda. (2014). Model-model pengajaran dan pembelajaran. Yogyakarta: Pustaka Pelajar.

Namdeo, R. P. (2012). Constructivism and pedagogical stratgies. Edusearch, Vol. 3. No. 2. 0976-1160.

Nana Sudjana. (2013). Penelitian hasil proses belajar mengajar. Bandung: PT Remaja Rosdakarya Offset.

Omar, N. Et. al. (2011). Automated analysis of exam question according to bloom's taxonomy. Procedia-Sosial and Behavioral Sciences, 59 (2012) 297-303.

Pardjono. dkk. (2007). Panduan penelitian tindakan kelas. Yogyakarta: Lembaga Penelitian UNY.

Presiden. (2005). Peraturan Pemerintah RI Nomor 19, tentang Standar Nasional Pendidikan.

Republik Indonesia. (2003). Undang - Undang RI Nomor 20, Tahun 2003, tentang Sistem Pendidikan Nasional.

Rusman. (2011). Model-model pembelajaran: mengembangkan profesionalisme guru. Jakarta: Rajawali Pers.

Savery, J. R., \& Duffy, T. M. (2001). Problem base learning: an instructional model and its constructivist framework. Bloomington: Indiana University. 
Sharma, S. (2012). Constructivsm: A new paradigm in education. Edusearch, Vol. 3. No. 2. 0976-1160.

Tan, Oon-Seng. (2004). Enhancing thinking through problem-based learning approaches: international perspectives. Singapore: (a division of).

Tan, Oon-Seng. (2009). Problem-based learningand creativity. Singapore: Singapore: Cengage Learning Asia Pte Ltd.

Thomas, K. (2004). Learning taxonomies in the cognitive, affective, and phsycomotor domain. Alchemy: Rocky Mountain.
Vardi, I. \& Ciccarelli, M. (2008). Overcoming problems in problem-based learning: a trial of strategies in an undergraduate unit. Inovations in Educational and Teaching International, Vol. 45, No. 4, 345-354.

Wardiman Djojonegoro.

(1998). Pengembangan sumberdaya manusia: melalui sekolah menengah kejuruan (smk). Jakarta: Sekretariat Negara.

Warsono \& Hariyanto. (2013). Pembelajaran aktif teori dan asesmen. Bandung: PT. Remaja Rosdakarya.

Wina Sanjaya. (2010). Strategi pembelajaran berorientasi standar proses pendidikan. Jakarta: Prenada Media Group. 